\title{
All that is the case: documents and Indexicality
}

\author{
Ronald E. DAY \\ Department of Information and Library Science, Indiana University, USA, roday@indiana.edu
}

\begin{abstract}
Resumen
Se discuten posibles epistemologías alternativas de la documentación, partiendo de la concepción otletiana, pasando por la reformulación de Suzanne Briet, hasta llegar al neo-documentalismo de Michael Buckland. En lo que respecta al plano teórico, se pone en diálogo el juego del lenguaje de Wittgenstein y la perspectiva de la documentación de Buckland. El principal objetivo es discutir las cuestiones de sentido y significado, apropiándose de los conceptos de presencia y ausencia indicativa. Se toman como objetos documentales de referencia algunas fotografías del difunto profesor Eduardo Murguía. Se llega a la conclusión de que el documento puede ser caracterizado no sólo como evidencia o prueba, sino como un índice, que puede revelar tanto lo que está presente como lo que está ausente en el registro documental.
\end{abstract}

Palabras clave: Murguía Marañón, Eduardo Ismael. Briet, Suzanne. Buckland, Michael. Documentos. Documentación. Presencia. Ausencia. Legado. Significado. Sentido. Referencia. Fotografias. Indecibilidad. Análisis de contenido.

It is common in modernity to define and discuss documents as being evidence in support of proof or facts. English language dictionary definitions commonly state this. It is stated in the beginning of Suzanne Briet's 1951 Qu'est-ce que la documentation? (Briet, 1951, 2006) through an appeal to the definition of "document" in Littré's dictionary. In Paul Otlet's work it is an assumption that underlies his entire project of documentation, in so far as his is a social project founded upon an epistemological presupposition, namely, naïve empiricism turned into a type of logical positivism, so that the world is known through the (bibliographical and documentary) logical organization of representations. In Michael Buckland's well known article, What is a Document? (Buckland, 1997), commenting on Suzanne Briet's work, this notion of document as evidence takes on renewed importance in terms of the work of information systems, namely to produce the evidence used in arguments (in the sense of bibliographies) and also to produce materials that may be used as evidence for arguments.

But what about documents that are not evidence of "facts" about the world (what Ludwig Wittgenstein in his Tractatus Logico-Philosophicus in a

\begin{abstract}
Three alternative epistemologies of documentation are discussed, starting from the Otletian conception, following with Suzanne Briet's reframing, and finishing with the neo-documentalism of Michael Buckland. Regarding the theoretical plane, Wittgenstein's language games and Buckland's perspective on documentation are brought one in front of the other. The main objective is to discuss the problems of significance and meaning, drawing on the concepts of indexical presence and absence. Some photographs of the late Professor Eduardo Murguia are taken as an example and reference. The author comes to the conclusion that documents can be characterized not necessarily as evidence or proof, but as an index, which can reveal both what is present and what is absent in the documentary record.
\end{abstract}

Keywords: Murguía Marañón, Eduardo Ismael. Briet, Suzanne. Buckland, Michael. Documents. Documentation. Presence. Absence. Legacy. Meaning. Sense. Reference. Photographs. Indecibility. Content analysis.

similar manner called "all that is the case"), but rather, which express what is not, rather than what is? The reference to Wittgenstein's early work is not fortuitous, for Wittgenstein's Tractatus is founded on the same two general epistemological premises that Otlet's notion of documents is founded on, except at the level of a propositional assertion, rather than documentary evidence, namely, a theory of reference as naming, and what often goes along with this in positivism, a correspondence theory of truth between statement and things. Such a position relegates all that is not the case to the realm of the "unsaid" (Wittgenstein, 1922), which in the Tractatus is the realm of non-truth conditions.

This realm of the unsaid is meaningless for fulfilling truth conditions, though it may be meaningful in other ways, namely as mystical experiences or even sensible performances that are part of the domain of representations for states of affairs in the empirical world. But these cannot be said because saying means, in this context, making truth conditional assertions. That there could be meaningful signs outside of these truth conditions, 
however, is the perspective that shaped Wittgenstein's later Philosophical Investigations, where statements that make truth assertions are just one of many sensible expressions or "games" of language.

In Philosophical Investigations the meaning of a term is not sought in a definition, but in a description of its use. Or to put this in the language of both philosophy (e.g., Frege's distinction between Bedeutung and Sinn) as well as documentary studies, the meaning or 'reference' of a term is sought by looking at its sense. Sense in Wittgenstein's 'Blue' and 'Brown' Books (composed from 1933-1935) is indicated by "grammar"- a term which needs to be understood both in a specifically linguistic and a non-linguistic, social, sense. In the Philosophical Investigations the notion of "grammar" is expanded to and replaced by "language games," which refers not only to linguistic grammar, but to the social uses of cultural forms that give language both sense and meaning (including reference).

Michael Buckland's article, Information as thing (Buckland, 1991) is the only Library and Information Science article that I know of that mentions mystical experiences as being possible "information." Buckland notes in parentheses:

(Note we are restricting our attention to physical things and physical events. Some people would say that some of their knowledge comes from paraphysical sources, notably from divine inspiration. Others would deny any such non-physical source of information, but, to the extent that it may exist, information science would have to be incomplete if it were excluded. Not knowing what to say on the subject we merely note it as a possible area of unusual interest within information science).

In noting such, Buckland opens the door to not just information being a thing, but in a work a few years later when he engages Briet's works (Buckland, 1997), he discusses things (or a being, an antelope) as being information, and more recently he more fully has discussed the problem of sense as context (Buckland, 2015).

I also note here Buckland's use of the word "may" in the quote above. This word acts as a conditional, indicating what could or can be the case. In this context, what could or can be the case is sensible, and so, meaningful. The term 'information' does not only refer to statements made to empirical referents, which can be said to be true or false. Rather, 'information' may also refer to meaningful statements that are not 'fact' based, in the sense of empirical reference. It can refer to possible historical events, to statements of fantasy, or to understandable mystical states-all dealing with sensible statements of what could be (or could have been, in the case of historical events) or can be, in the sense of conditionality, the case. This will be important to our discussion further on.

Returning to Briet's Qu'est-ce que la documentation?, we should note that in this book's opening page the definition of documents as being proof or evidence is immediately problematized by her as being incomplete, with Briet modifying this definition with the further qualification that a document is an indice (an indexical sign). Indeed, this qualification removes both documents and evidence from the realm of 'direct naming' (where the name and the named, like a definition and what is defined, appear to remain in the same scale of meaning, even if their documentary form-for example, the transition from an article to its abstract-changes) to a world of pointing between different regimes or senses.

This is a certain type of 'advance' upon Otlet's definitional sense of documentary evidence as resting on a correspondence of meaning, without much regard to sense. In Otlet's work, a document is 'about' something and that aboutness is repeated through higher and higher levels of abstraction without loss of meaning. In Briet's epistemology, however, there is no guarantee for preventing a loss or shift of meaning, as discourses about the named entities follow the documentalist's act of naming in "initial" documentation (taxonomies and ontologies) and these discourses may contain their own grammars or language games so that the meaning or reference of the entity changes because its sense changes. For example, compare the different senses for 'water' in ecology (e.g., 'lake' or 'stream,') and chemistry ('e.g., "H20).

(In philosophy these English terms, "reference" and "meaning," are sometimes used synonymously and sometimes not; it depends on whether we view meaning starting from the perspective of empirical reference or from the perspective of sense. From the first perspective, the meaning of a term is its reference, but from the second perspective, the meaning of a term is a product of its sense, which then gives it reference, though this reference may involve other than empirical referents-e.g., fantastic references, such as to unicorns and such.)

From the type of what we'll call 'logical positivism' of Otlet's epistemology, sense is only possible in truth conditions, which Otlet sees as grounded in scientific statements, ambiguously understood as both being contained in and acting as 'documents' of the world. Documents are then either sensible or not. Briet's notion of documents, however, shifts the grounds of evidence to that of ev- 
idence's own definition by social processes of ontology creation and discursive formation. Documents are evidentiary only because of cultural and social systems of naming and discourses. And so, things (such as antelopes) can be documents, because they are treated not only as signs, but as a very specific sort of sign, one that goes beyond 'signs' as naming functions alone, namely, indices. Documents are no longer about things, but are things that are 'about.' The manner in which things come to be 'about,' or evidence, is the process of the creation of meaning, and though Briet doesn't go very far in investigating this, these are the possibilities and limits of sense that cultural and social systems attribute to signs as meaningful or 'semiotic' signs.

Understanding signs as indices, rather than as direct or essential representations, is an important step in helping us understand documents as not being about facts, but being about the possibility of facts, even in their absence. It is a step that begins to remove us from what Derrida called a 'philosophy of presence' and from a trust in 'information' as being a signifier of truth conditions, rather than possibilities for knowledge, belief, and trust. It is a step toward a greater accountability of 'facticity' (the status of being a fact) and what I call 'evidentarity' (the status of being evidence) than is possible if one keeps the notion of documents and documentation restricted to a naïve empiricist or positivist account of signs and texts in 'science.' Which is to say that it also frees 'science' from an account of facts and evidence that itself is inscribed in a historical metaphysics of 'documentarity,' where 'the facts' of beings are seen as 'written' in their common species-being, morphology, DNA, or whatever is the 'essence' or the substrate that is seen as the essential marker of being for a being or for beings. For thinking evidentiary signs as sense, and sense as the roots of meaning, is an important step in seeing beings even in their very absence of being. If we can't account for this, then we have no ability to account for all 'non-factual facts,' namely mystical states, 'fiction,' and all sort of expressions that are sensible, and may even be truthful in some other way than a correspondence theory of truth tied to an empirical realism.

This problem of meaning as a correspondence theory, reaches back to iconic modes of representation and medieval theories of the correspondence of intellect and things (adaequatio intellectus et rei). Along with Wittgenstein's work, in $20^{\text {th }}$ century modernity this theory of meaning and of truth was challenged by theories of relativity and phase states in physics, metonymy and grammar in linguistics, and performativity in the arts. Broadly we could perhaps summarize these as theories of indexicality. Rather than being propositional or documentary statements, rather than being representational images of things and 'states of affairs,' signs and coherent collections of meaningful signs (documents) have metonymical positions within activities in the world. Facts are constructed by both meaningful signs and by activities with affects and effects. But, this is also to write that the domain of 'facts' is not limited to scientific statements as modes of representation. Such a claim is complementary to the claim that 'science' should not be understood as representational activity, or to put it another way, as a 'documentary' form in the mode that Otlet saw documents and an epistemology of documentation. Rather, science like all other products of experience and description has its meaningful entities because they are products of sensible activities.

To understand all this better, within the context of a document that can only be understood as an index, and not as a 'fact' (in the mode of representing only what is as present), let me appeal to a photograph taken shortly before the death of Professor Eduardo Ismael Murguia Marañon by Professor luri Rizzi. Photographs are often taken as iconic representations of only what is present, so appealing to a photograph as an index of what is not present is to push both a traditional epistemology of photography and also Otlet's documentary epistemology (based on the model of photography as direct representation, as shown in Otlet's Traité de documentation (Otlet, 1934)) to their opposing limits.

This photograph appeared in the social networking site of Facebook a few days before Eduardo Murguia's death. It is a photograph of the bookcase in his apartment, with an empty chair in front of it. A chair that is positioned as if for a portrait, in the bourgeois, academic tradition of learned men being photographed in front of their personal libraries. The bookcase looks like what I saw when I visited Eduardo ten months earlier with my friend and his colleague, Professor Marcia H.T. de Figueiredo Lima, when Marcia took a photograph of Eduardo and me (Figure 2).

When Rizzi first posted his photograph on Eduardo's Facebook page, I took it as a sign of Eduardo's death, but then reading on, I found that the photographer had been visiting Eduardo when he took this photograph. Perhaps I could be forgiven my initial assumption given my understanding that Eduardo was suffering from a several year battle with kidney cancer, and given the contrast with the earlier photograph of the two of us, in which he stood where in the later photograph is an empty chair. 


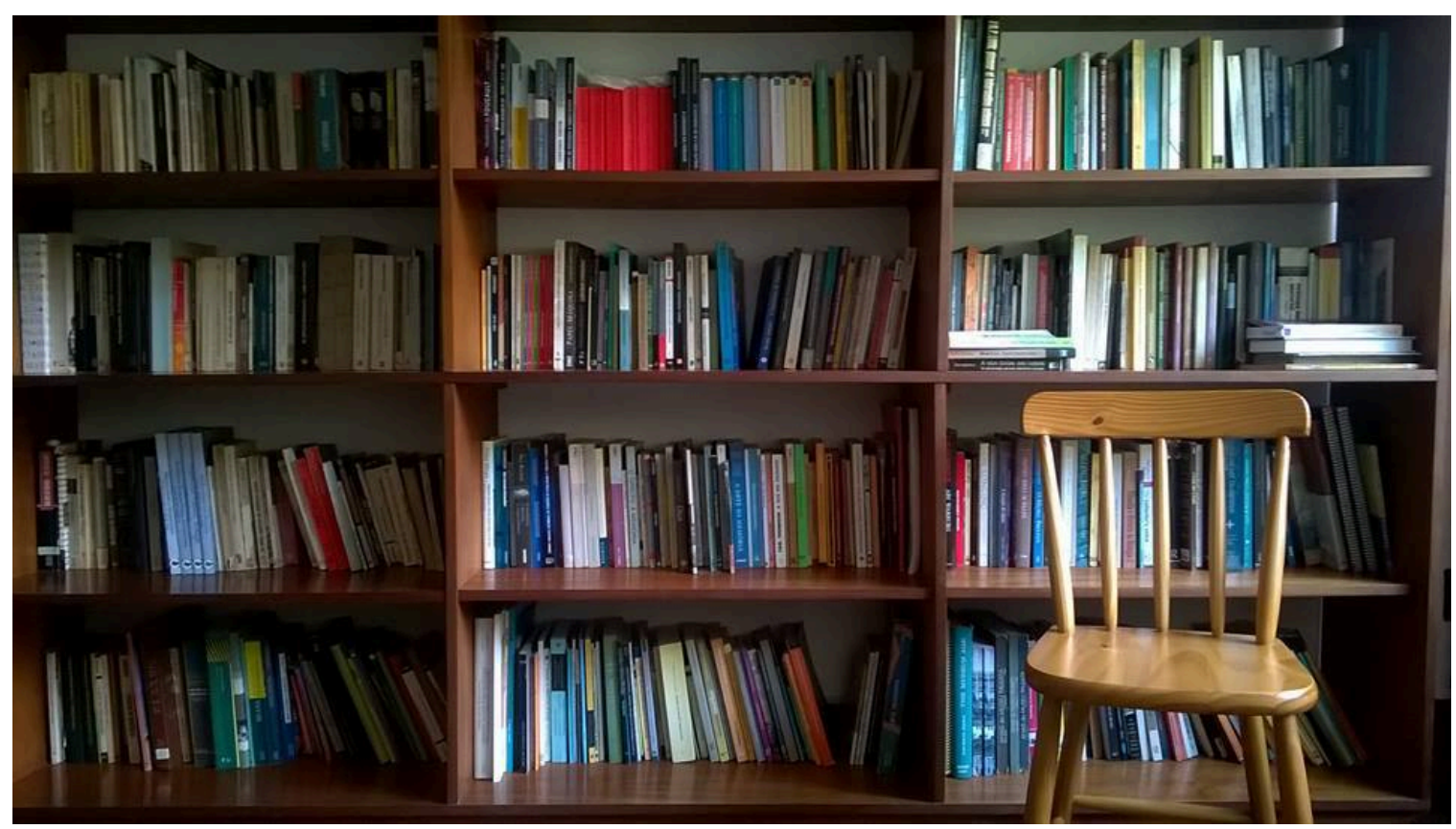

Figure 1 (Reproduced with the permission of the photographer, Professor luri Rizzi)

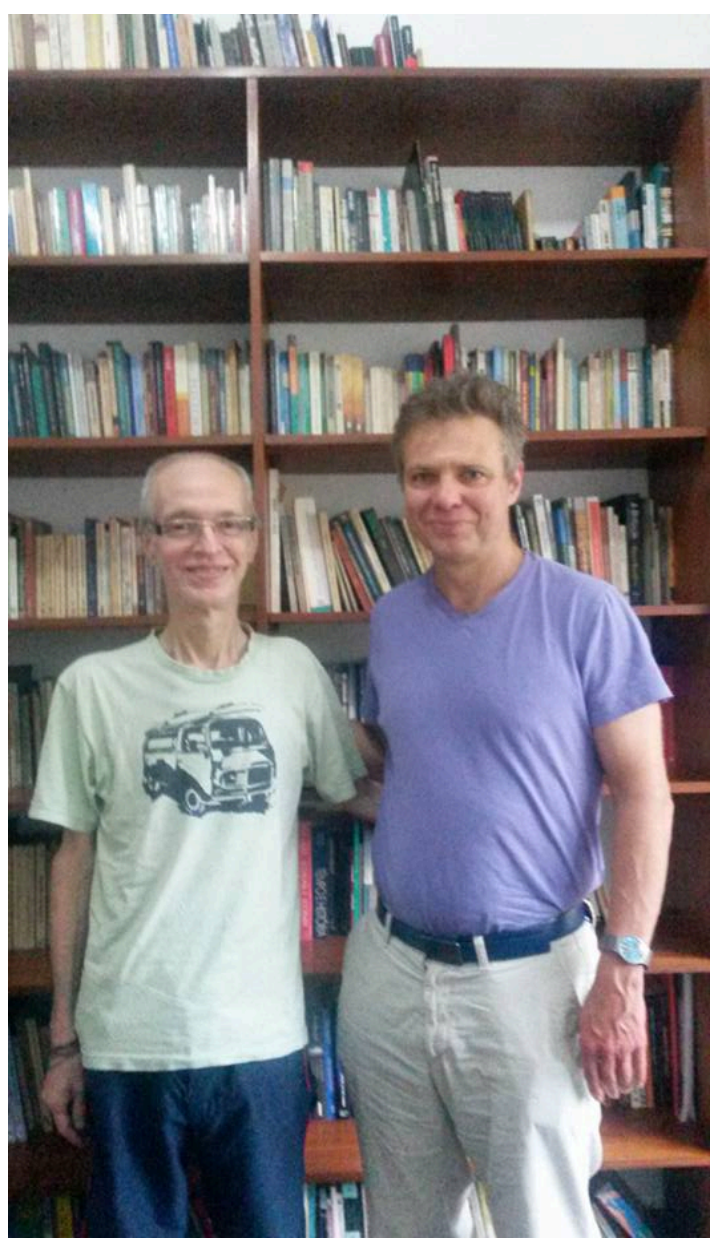

Figure 2 (With permission of the photographer, Professor Marcia H.T. de Figueiredo Lima)
Once I learned that Eduardo was still quite present in this life, then I must admit that the index of that empty chair turned to myself, and to the thought that just as Eduardo may soon be absent from the earlier photograph, so too I will be one day, and so, too, this photograph will rapidly disappear in human history. The transition from the earlier to the later photograph suggests to those who are aware of the context, the passing of a life. But Rizzi's photograph in itself suggests both the passage and the passing of a life, precisely because the owner of the apartment and the books, the person who should be sitting in the chair for his portrait, is absent.

There are all sorts of questions of evidence that Rizzi's photograph suggests. What does it index and how? How is it that Eduardo was both absent from the photograph of what is posed as his portrait, while he remained still alive? How do both his presence and his absence appear in the photograph, despite the fact that he is not present and yet he is also not absent from it (whether one knows that he was alive or not at the time)? How does this photograph suggest not a presence of a person per se (since that person is absent from the photograph), but a potential physical absence? And how does the photograph perform both a future anterior tense ("x will have been") and what is called in English the "going-to future" tense, where what is present is carried into the future ("This event is going to happen")?

If documents (not the least, photographic documents) are merely evidence of what is, and what 
is, in the photograph, must be the portrait of Eduardo in order for the photograph to be about Eduardo, then Rizzi's photograph could not have any meaning (at least in regard to being about Eduardo) for Eduardo is absent from the photograph. From a viewpoint of strict representation, we would have to say that Franco's photograph was 'mystical,' and as the early Wittgenstein had it, we would have to pass over it in silence. But Rizzi's photograph does quite the opposite, for it invokes an entire life, especially for those who knew Eduardo and were present with his books and bookcases.

It isn't just an issue of 'reception theory,' but rather, the photograph speaks of a shared life, which involves many people not in the photograph. This life extends beyond the one who is, at the center of attention, and not the least by his absence. In this regard, I might also point to the further uses of Rizzi's photograph on Eduardo's Facebook site after his death, where Rizzi's photo is covered by a rainbow or 'Gay' rainbow flag, in celebration of Gay (i.e., homosexual) rights (a mechanism of digital superimposition that Facebook provided in celebration of the United States Supreme Court decision on the legality of homosexual marriages in that country in 2015, a few weeks after Eduardo's death). And I could point to further postings done on Eduardo's site many months after his death, either automatically performed through Facebook's algorithms which allow a user to have posted on his or her page any mention of him by his or her Facebook 'friends' or through Facebook 'friends' who may not have been aware of his death. Indeed, Facebook pages suggest that at least the documentary life of the deceased does not end after his or her death.

We could say that documentation leads to lives beyond physical death, but it is perhaps better to suggest that what we call 'my' life precedes and extends beyond the physical 'me,' and is literally, 'our life,' in so far as we live as cultural and social beings, and particularly in modernity, as often mediated by documentary technologies that constitute 'our life' in temporal and spatial manners that exceed our physical being. In this way, literary we are, and only together as 'we' are we, what Suzanne Briet called in Qu'est-ce que la documentation? "homo documentator."

But who and what is this "homo documentator" about? In modernity documents are thought of as materials that 'fix' or 'store' information as their contents. This fixing and storing is thought to be an act of permanent recording. But what we see in Franco's photograph is not the fixing and storing or even the permanence of what is, but rather the indexing of what is not shown by what is shown. Namely, what the photograph shows is an aspect of Eduardo's life, and so what the photograph is about is not only Eduardo, but also a shared documentary community to which his life then, and still in some ways, belongs. This documentary community, this life, is what is shown. Indeed, to return to the early Wittgenstein, it is shown in its very absence of being 'said,' or at least without being said with Eduardo himself as the center of, literally, its pictorial and strict referential focus. Or in other words, it is the 'grammatical sense,' 'the way of life,' of the signs both 'within' and beyond the photographic document that give the photograph its meaning or reference.

This sense has a lot to do with the 'social life' of the photograph, as well as the social life of books and the social life of the books shown in the photograph, which inscribe and express communities which both composed and shared Eduardo's life in certain of its important aspects. Far from signifying a representational 'homo documentator,' the photograph on Facebook harkens back to a pre-modern function, namely as a token of communal memory, in the way that the Andean quipu (or khipu), which were means of record keeping through grass branches and knots, formed memories, largely numeric, but perhaps historical as well (Mignolo, 2003). Records, here, didn't 'fix' meaning in a representational content, but rather evoked meaning by their indexical relay between signifying and socio-cultural orders in specific situations. Likewise, Franco's photograph is evocative for a community. Its evocation is that of the life of a community in which a specific person, a specific time or set of 'present' times, are centrally involved, not because they are necessarily shown, but because, like all meaningful signs, they are implicated in the cultural signs of the photograph and their social circulation simultaneously.

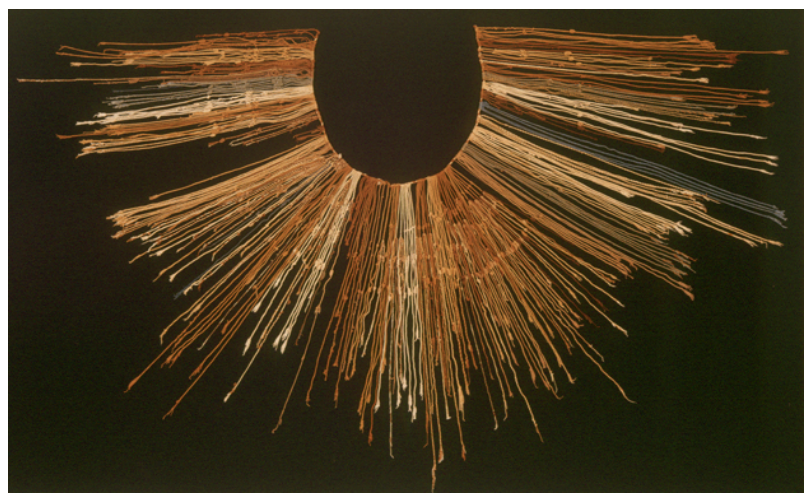

Figure 3. A quipu from the Larco Museum Collection; cited in Wikipedia ("quipu"); copyright, Creative Commons BY-SA 3.0 
The indexicality of a document doesn't just belong to or lie in the content or signs of a document. But rather, it inhabits the role of documents in lives, which give life to one's self and to others even when they are absent. This is sometimes referred to in English as 'the life of the mind,' but it isn't just one mind that is at issue here, but a social life of cultural forms and social norms in the deployment of signs, and so, of the inscription of lives and a 'life.' It isn't just that written texts (however one wants to understand this term) have the power to transmit meaning beyond death (do they have any ability to 'transmit' anything?), but rather that they act as fulcrums for the leveraging of powers beyond the 'presence' that any single one believes and acts as they are, because they are communal. Or to put it another way, they act for all that is not the case, in so far as they remain poised to overcome the present in the fulcrum of past and present into the future. This is why the photograph can be about Eduardo, even then or now in his absence in the photograph or physically on this earth. 'Our lives' precede and follow 'me' thanks to meaningful cultural forms (e.g., 'language') in social norms of deployment and thanks to the technical and technological mediums of such. These mediums shape our lives, not only when I am alive, but following 'me.'

A fulcrum, like the chair in luri Franco's photograph, is sometimes made of wood. It can store power, both by the flexibility of its own material and by serving as a harbor for a resting body. A chair only has meaning as a tool of form and function (or that's how 'aboutness' is determined by the Art and Architecture Thesaurus, which treats it as a type of furniture, just as any particular work of literature is sometimes treated by catalogers as a type of genre form and function-'fiction,' or a 'novel' for instance). The chair sits empty, just as the books sit on the shelves, for purposes of being used toward some end, and valued as potentials of personal or cultural knowledge. They store potential powers in their very structures. These potentials are made up of cultural, social, and physical (i.e., the body, including the brain) affordances for expression, and so, for identity.

Franco's photograph documents not simply any objects, but objects belonging to a type of being for whom his or her future belongs to the objects as much as the objects belong to his or her future. The documents on Eduardo's shelves stood and still stand in the photograph, not simply as objects that 'contain' other minds, but rather as indexes of powers of mind, toward conditions of mind, conditions of expressions. "Mind" is an individual term of personal expression and potential expressions only because it is part of common cultural forms and social norms. "Mind" as a personal term lies in these commonalities of expression, and so can only be said to exist as a part of a 'communal mind.' Conditions of mind are not random, but rather, they are part of series of expressions that could exist as meanings in the world because there are the affordances of life and expression that allow them to exist. That is, they could exist because they can. The factuality of documents must adhere to something believed to be possible. This possibility is the source of truth conditions, of which the 'empirical,' including empirical referents, are only one function.

So, the answer as to how Eduardo could be both present and absent in Franco's photograph is this: because what it shows is a human life, and specifically the human life that was Eduardo's. A human life is known by the powers of that being which is known as a human being. This is a being which doesn't just 'use' documents, much less use them for what they 'contain,' but rather, which sets up a sense of a life by means of documents and their signs, including their availability on shelves, in databases, etc. And this is what a library is: a storehouse of affordances for activating a life within domains of ways of life, and a personal library is the means toward a very specific life.

These lives are not just expressive, but connective, because each life is part of larger, literally, senses of life. And so, each life has many lives within it, not simply because it has many sources of potential powers from its own experience, but because it continually draws from the 'external' resources that gave it these experiences. And for this reason, as well, a life can continue to live on through the document of the photograph, even after the possessor of the library passes on, and even after the library is disassembled and the apartment sold and someone else moves in. Or even when he or she is absent from the photograph. For the photograph doesn't contain a person or anything else, but rather, it is a material in ways of life for us, and so it is a document because of what is read, said, and in general, acted through it. Photographs first of all index ways of life within which they are 'content.'

The portrait of a life remains in the absence of the body by means of the promise of the body, and this body, most particularly with human beings perhaps, gains its sense through social and cultural norms and forms for expressions, upon which it hangs. The indice of the photograph are made up of the meaningful strands of a life. These strands assure a virtual, social and cultural, 'going to be,' and they assert a 'will have been.' Why? Because this is what a human being is, for other human beings, and most of all for his or her self. A person documents him or herself in 
this intending and having been. A photograph is performed for the present, but it represents unforeseeable futures that immediately view it as a past once the photograph is taken. To have a photograph without one's self where one's self is expected to be present is to have a past that may suggest an absent future, but that future cannot be absent.

Thus, knowledge in Franco's photograph cannot be restricted to 'scientific' or 'empirical' knowledge of the photograph's content, but rather covers these as well as other forms of 'what is the case' in relation to the content. We are informed not by the supposed content of the photograph, but by our relations to what we suppose is the content, and knowledge settles out in accordance with the types of expressions and expectationsthe sense and references-that form these relations. This 'accordance' or "adaequatio" is what a documentary life is.

For better or worse human beings act within a vastly expanded world of senses beyond empirical referents, and these empirical referents are indeed only possible as knowledge because of these senses. This is the human Umwelt that I read through Franco's photograph. This is the event of the document, thanks to those who can read these words and can understand this document. This is the event of the documents that made up Eduardo's library, as they were and will be. And so this is also the absence that I anticipate of my own body, that both was, and virtually could and can still be found in Eduardo's library, thanks to documentary mediums. Such events are present and central to the human Umwelt.

Eventually your body will betray you, and all you will be known by is (your) affects. This is "all that is the case," and this is what these photographs show. This is the mystery which, fundamentally and ultimately, any document presents to us. This is its ethical purpose and its aesthetic form.

\section{References}

Briet, S. (1951). Qu'est-ce que la documentation?. Paris: Édit/Éditions Documentaires.

Briet, S. (2006). What is Documentation?: English Translation of the Classic French Text. Lanham, MD: Scarecrow Press.

Buckland, M. K. (1991). Information as Thing. // Journal of the American Society for Information Science, 42(5), 351360

Buckland, M. K. (1997). What is a document? // Journal of the American Society for Information Science, 48(9), 804809

Buckland, M. K. (2015). Making sense \& using logic. Paper presented at the International UDC Seminar 2015, Lisbon, Portugal.

Mignolo, W. (2003). The darker side of the Renaissance: literacy, territoriality, and colonization (2nd ed. ed.). Ann Arbor: University of Michigan Press.

Otlet, P. (1934). Traité de documentation: le livre sur le livre: théorie et pratique. Brussels: Editiones Mundaneum, Palais Mondial.

Wittgenstein, L. (1922). Tractatus logico-philosophicus. New York and London: Harcourt, Brace \& Company, Inc.; K. Paul, Trench, Trubner \& Co., Ltd.

Enviado: 2016-02-15. Segunda versión: 2015-02-15. Aceptado: 2016-04-25. 
